\title{
Tradisi Adat Pattaungeng Situs Tinco di Soppeng, 2007-2017
}

\author{
Eka Yanti, Jumadi, Muh. Rasyid Ridha \\ Prodi Pendidikan Sejarah Fakultas Ilmu Sosial Universitas Negeri Makassar \\ khaekayanti@gmail.com
}

\begin{abstract}
Abstrak
Tujuan penelitian ini adalah untuk mengetahui latar belakang keberadaan Tradisi Adat Pattaungeng, proses pelaksanaan serta cara masyarakat mempertahankan Tradisi Adat Pattaungeng Di Situs Tinco. Penelitian ini menggunakan metode sejarah yang terdiri atas 4 tahapan yaitu heuristik, kritik, interpretasi serta historiografi.Hasil penelitian menunjukkan bahwa Tradisi Adat Pattaungeng merupakan kegiatan tahunan yang telah dilaksanakan secara turun temurun. Pemerintah mulai ikut berpartisipasi mulai tahun 2012. Faktor pendukung yang menyebabkan pelaksanaan Tradisi Adat Pattaungeng masih tetap dilaksanakan oleh masyarakat di daerah tinco yaitu adanya niat dari dalam diri untuk membudayakan dan melestarikan tradisi adat pattaungeng, adanya penerus atau pergantian generasi yang akan melaksanakan sehingga budaya tersebut tetap terlaksana dan bertahan didalam masyarakat. Tradisi tersebut dilaksanakan antar bulan september-oktober.Berdasarkan hasil penelitian di atas dapat disimpulkan bahwa masyarakat di Tinco melakukan Tradisi Adat Pattaungeng dengan keyakinan bahwa tradisi tersebut di laksanakan untuk tola bala, untuk keselamatan dan kesejahteraan agar terhindar dari bencana. Serta ucapan rasa syukur kepada Tuhan atas reski yang berlimpah di berikan Tuhan kepada mereka.
\end{abstract}

\section{Keyword: Tradition, Pattaungeng, Tinco}

\begin{abstract}
The purpose of this study was to determine the background of the existence of the Pattaungeng Indigenous Tradition, the implementation process and the way the community maintained the Pattaungeng Indigenous Tradition on the Tinco Site. This study uses a historical method consisting of 4 stages, namely heuristics, criticism, interpretation and historiography. The results showed that the Pattaungeng Traditional Tradition is an annual activity that has been carried down for generations. The government began to participate starting in 2012. Supporting factors that led to the implementation of the Pattaungeng Indigenous Tradition are still carried out by the community in the Tinco area, namely the existence of an inner intention to cultivate and preserve the pattaungeng traditional traditions, the successor or succession of generations who will carry out so that the culture remains implemented and survived in society. The tradition is carried out between September-October. Based on the results of the above research it can be concluded that the people in Tinco carry out the Pattaungeng Traditional Tradition with the belief that the tradition is carried out for tolaala, for safety and prosperity in order to avoid disaster. As well as gratitude to God for the abundant blessings God gave them
\end{abstract}

\section{Keyword: Tradition, Pattaungeng, Tinco}

\section{A. Pendahuluan}

Sulawesi Selatan merupakan provinsi yang memiliki baragam kebudayaan dan kesenian tradisi, hal ini dipengaruhi oleh masyarakat Sulawesi Selatan yang mempunyai berbagai macam suku mayoritas yaitu Bugis, Makassar, Mandar, 
Toraja. Dari empat suku tersebut masingmasing memiliki kesamaan tradisi.

Tradisi merupakan sesuatu yang telah dilakukan untuk sejak lama dan menjadi bagian dari kehidupan suatu kelompok masyarakat. sedangkan tradisi diartikan sebagai adat kebiasaan turun-temurun dari nenek moyang yang masih dijalankan dalam masyarakat dan anggapan bahwa cara-cara yang telah ada merupakan yang paling baik dan benar. Adat merupakan pencerminan kepribadian sesuatu bangsa dan merupakan salah satu penjelmaan jiwa bangsa dari abad ke abad. Oleh karena itu, bangsa di dunia memiliki adat kebiasaan sendiri-sendiri yang satu dengan yang lainnya tidak sama. Karena ketidaksamaan inilah dapat dikatakan bahwa adat merupakan unsur yang terpenting yang memberikan identitas bangsa yang bersangkutan.

Tradisi di setiap daerah pasti memiliki ciri-ciri yang berbeda, tradisi tersebut telah menjadi ciri khas yang membedakan antara satu daerah dengan daerah lainnya, dan merupakan warisan dari nenek moyang dan leluhur secara turun temurun. Indonesia merupakan daerah yang masih tergolong mampu mempertahankan tradisinya ditengahtengah kehidupan modern, namun tidak nguntuk menyesuaikan tradisi dengan perkembangan zaman.

Tingkat peradaban, maupun cara penghidupan yang modern, ternyata tidak mampu menghilangkan adat kebiasaan yang hidup dalam masyarakat. Dalam proses kemajuan zaman yang tampak, bahwa adat tersebut menyusuaikan diri dengan keadaan dan kehemdak zaman, sehingga adat itu menjadi kekal serta tetap segar. Adat-istiadat yang hidup serta yang berhubungan dengan tradisi rakyat inilah merupakan sumber yang mengagumkan bagi pembinaan dan pengembangan kebudayaan bangsa indonesia. Adat, Tidak dapat dipisahkan dengan kebudayaan bahkan adat adalah bagian kebudayaan suatu suku bangsa. (Wahid, 2007)

Seperti halnya di Sulawesi Selatan memiliki beragam kebudayaan dan tradisi yang masih terpelihara dengan baik dan masih dilaksanakan sampai saat ini yang telah menjadikan masyarakat yang berbudaya. Salah satu tradisi yang ada di Sulawesi Selatan khususnya di Kabupaten Soppeng, adalah tradisi yang disebut oleh masyarakat setempat dengan Pattaungeng yang khususnya dilakukan oleh masyarakat Tinco.

Anggapan masyarakat Tinco terhadap Tradisi Adat Pattaungeng merupakan suatu bentuk upacara keagamaan yang bersifat sacral (suci) yakni suatu kekuatan simbolis atau tindakan sekaligus sebagai wujud dari ekspresi jiwa mereka.

Penelitian tentang tradisi adat Pattaungeng yang dilakukan di situs tinco Kelurahan Ompo Kabupaten Soppeng merupakan suatu kajian kebudayaan lokal dengan menggunakan pendekatan Ilmu Sejarah secara khusus. Meskipun telah banyak lahir penelitian-penelitian maupun tulisan-tulisan yang menyangkut atau terkait dengan tradisi yang berkembang dimasyarakat. Misalnya Ttradisi Pattaungeng di situs Bulu Matanre Desa Mattabulu Kacamatan Lalabata Kabupaten Soppeng yaitu skripsi yang di tulis oleh Rizky Arafiki tahun 2017. Pada penelitian ini penulis mendeskripsikan fungsi sosial dari tradisi Pattaungeng, rangkaian pelaksaan, siapa yang melaksankan tradisi, waktu pelaksanaan dan perangkatperangkat yang digunakan dalam tradisi tersebut. (Arafiky, 2017)

Salah satu upacara adat yang masih dilestarikan dalam lingkungan masyarakat Tinco Kelurahan Ompo Kecematan Lalabata Kabupaten Soppeng adalah pelaksanaan tradisi adat Pattaungeng, yang merupakan tradisi untuk menghormati dan syukuran atas hasil panen yang diperoleh. Tradisi Pattaungeng sampai sekarang tidak diketahui kapan pertama kali dilaksanakan karna tradisi tersebut merupakan warisan nenek moyang.

\section{B. Metode Penelitian \\ Metode merupakan sebuah cara prosedural untuk membuat dan}


mengerjakan sesuatu dalam sebuah sistem yang teratur dan terencana. Terdapat persyaratan yang ketat dalam melakukan sebuah penelitian, yaitu prosedur yang sistematis. Menurut Sartono Kartodirdjo, metode merupakan cara bagaimana seseorang memperoleh pengetahuan ( how to know ) (Madjid, 2014). Terdapat empat langkah metode sejarah yang wajib hukumnya dilaksanakan oleh sejarawan dalam penulisa karya sejarah, yaitu heuristic (pengumpulan sumber), kritik sumber (eksternal/bahan dan internal/isi), interpetasi (penafsiran), dan historiografi (penulisan kisah sejarah).

\section{Heuristik}

Berasal dari bahasa yunani heuristiken yang berarti menemukan atau mengumpulkan sumber. Dalam kaitannya dengan sejarah tentulah yang di maksud dengan sumber yaitu sumber sejarah yang berupa catatan kesaksian, dan fakta-fakta lain yang dapat memberikan gambaran tentang sebuah peristiwa yang menyangkut kehidupan manusia.

\section{Kritik}

Tahap kedua dalam penelitian sejarah adalah kritik sumber.Hasil yang ingin dicapai pada tahap ini adalah didapatnya sumber sejarah yang benar-benar memvberikan fakta guna merekonstruksi masa lalu, terdapat dua aspek yang harus diverifikasi yaitu Otentisitas atau keaslian sumber, dan kredibilitas atau tingkat kebenaran informasi dari sumber sejarah.

Penentuan keaslian suatu sumber berkaitan dengan bahan yang dgunakan dari sumber tersebut, atau disebut kritik eksternal. Sedangkan penyeleksian informasi yang terkandung dalam sumber sejarah, dapat dipercaya atau tidak dikenal dengan kritik internal. Setiap sumber sejarah diperlakukan sama, yakni diseleksi baik dari segi eksternal maupun internalnya. Tahap penyeleksiannya harus sistematis, yaitu diawali dengan kritik eskternal dan kemudian kritik internal. Jika tahap pertama suatu sumber sejarah tidak memenuhi syarat sebuah sumber sejarah (dari segi otentisitasnya), tidak perlu dilanjutkan verifikasi berikutnya (Hamid \& Madjid, 2008).

\section{Interpretasi}

Tahapan ini merupakan setelah kritik sumber.Sumber-sumber yang telah didapatkan perlu ditafsirkan oleh peneliti.Dalam tahap interpretasi, imajinasi seorang peneliti dibutuhkan untuk menafsirkan seluruh kejadian berdasarkan data-data yang terkumpul. Pada hakikatnya,interpretasi sejarah seringkali disbut dengan analisis data sejarah. Dalam hal ini, ada dua metode yang digunakan yaitu analisi dan sistesis.Keduanya dipandang sebagai metode utama dalam sintesis atau sejumlah fakta yang diperoleh dari sumber-sumber sejarah dan bersamasama dengan teori-teori disusunlah fakta itu dalam suatu interpretasi yang menyeluruh. Interpretasi dapat dilakukan dengan cara membandingkan data yang telah diperoleh sehingga seorang peneliti mampu menyusun fakta-fakta sejara yang dapat dibuktikan kebenarannya

\section{Historiografi}

Tahap ini merupakan tahap terakhir dalam penelitian sejarah. Pada tahap ini peneliti akan menuliskan peristiwa sejarah tersebut dalam sebuah tulisan yang dalam penulisan, pemaparan dan pelaporan menggunakan tata cara tertentu. Dimana dalam hal ini, penelitian yang peneliti lakukan adalah penelitian dengan kajian keperpustakaan dan lapangan. Penulisan sejarah merupakan proses penjelasan dari semua kegiatan dalam proses penelitian sejarah. Pada tahap ini penulis mencoba untuk menggambarkan hasil penelitiannya. Dalam hal ini pada penelitian tentang Tradisi Adat Pattaungeng di Situs Tinco Soppeng (2007-2017)

\section{Tinjauan Umum Lokasi Penelitian}

Watansoppeng, yang merupakan daya tarik kawasan ini. Masyarakat Sulawesi Selatan bahkan memberi julukan Watansoppeng sebagai kota kelelawar. Kabupaten soppeng yang beribukota di Watansoppeng terletak antara $40^{\circ}$ Lintang Selatan dan $4^{\circ} 32$ Lintang Selatan dan antar 
$119^{\circ} 47^{\prime} 18^{\prime}$ 'Bujur Timur dan $120^{\circ} 06^{\prime} 13^{\prime}$ ' Bujur Timur. Di sebelah timur secara administrasi berbatasan dengan Kabupaten Wajo dan Bone. Di sebelah utara berbatasan Langsung Dengan Kabupaten Sidenreng rappang.sedangkan di sebelah Barat dan Selatan di batasi oleh Kabupaten Barru dan Kabupaten Bone. Kabupaten Soppeng merupakan daerah dataran dan perbukitan dengan luas wilayah $1.500 \mathrm{Km}^{2}$. Dengan luas daratan $700 \mathrm{Km}^{2}$ berada pada ketinggian rata-rata kurang lebih $60 \mathrm{M}$ di atas permukaan laut.

Kelurahan Ompo merupakan salah satu kelurahan yang berada dalam wilayah Kecematan Lalabata. terletak lebih kurang enam kilometer di sebelah utara Watansoppeng masuk dalam wilayah Kecematan Lalabata, Kabupaten Soppeng. Letak astronominya $119^{\circ} 52^{\prime}$ 32" BT dan $4^{\circ} 19$ '33” BS. Kawasan ini merupakan dataran tinggi yang membujur dari timur ke barat. Di sebelah baratnya bersambung dengan perbukitan Lawo, sedang di sebelah timurnya adalah dataran rendah. Di sebelah selatan dan timur membentang persawahan penduduk yang merupakan sawah teknis dengan sumber air dari sumgai Lawo.

Berikut gambaran tentang Sejarah Perkembangan Kelurahan Ompo

a. Batas Wilayah

Sebelah Utara Desa Pesse, Sebelah Selatan, Kelurahan Lapajung, Sebelah Barat, Desa Mattabulu, Sebelah Timur, Kelurahan Salo Karaja

b. Luas wilayah

Luas wilayah Kelurahan Ompo sekitar $23 \mathrm{Km}^{2}$ dan pada umumnya masyarakat bermata pencaharian sebagai petani. Luas lahan pertanian yang ada adalah 71,5 ha

\section{Pembahasan}

\section{Latar Belakang Keberadaan Tradisi Adat Pattaungeng}

Di dalam masyarakat Indonesia terdapat beraneka ragam budaya antara lain berupa upacara tradisional dan adat istiadat yang perlu dilestarikan, karena di dalamnya terkandung makna nilai-nilai luhur yang tinggi yang dapat mempengaruhi masyarakat pendukungnya untuk berinteraksi secara aktif dan efektif sehingga mampu membina budi pekerti luhur. Sifat keanekaragaman masyarakat dan kebudayaan Indonesia tersebut dapat dipersamakan dengan suatu lukisan mozaik yang secara keseluruhan manggambarkan nilai-nilai budaya bangsa. Seperti halnya sebuah bingkai warna merupakan unsur keseluruhan yang hanya dapat dipahami dalam hubungan kebudayaan sebagai suatu kesatuan. (Purwadi, 2007)

Pada umumnya tradisi-tradisi yang ada di Indonesia merupakan warisan dari generasi sebelumnya. Tradisi tersebut ada yang mengalami perubahan dan kemudian hilang, ada juga yang dipelihara dan dikembangkan sehingga dapat disaksikan oleh generasi selanjutnya. Upacara adat atau tradisi itu semula merupakan pemujaan terhadap para leluhur yang kemudian menjadi wilujengan (permohonan selamat) terhadap Tuhan dan leluhur tersebut.

Setiap kerajaan, utamanya yang keberadaannya diawali seorang raja atau pun ratu yang berasal dari to manurung. Sebagai lambang kebesaran dan kekuasaannya adalah berupa benda yang disebut dengan Arajang . Arajang berasal dari kata raja yang berasal dari kata raja yang berarti besar yang dalam bahasa makassar disebut Kalompoang. Sebagai Arajang, dapat berupa senjata tajam (keris, kalewang, tombak dan lain-lain) atau dapat berupa perhiasan, rambut dan benda yang dianggap sakral (keramat). Fungsi utama dari Arajang ini adalah untuk menambah kharisma dan wibawa seorang raja sebagai seorang pemimpin dan pemersatu.

Di daerah Soppeng, benda-benda yang dianggap sebagai arajang adalah berupa gulungan rambut yang konon dimiliki la Temmamala Manurungnge ri Sekkanyili, menurut kisah, suatu ketika ia meminta agar rambutnya ikellu (dicukur habis hingga gundul) dan setelah rambut nya habis tercukur, maka iapun mallajang. Tempat dimana ia cukur itu kemudian dinamakan situs Tinco. Disitus tinco di temukan 
bongkaha batu yang kemudian di sebut Lakelluaja, yaitu berasal dari kata Ikellu'i Nallajang yang artinya rambutnya dicukur gundul maka ia pun menghilang.

Secara etimologi Pattaungeng berasal dari kata Taung dalam bahasa bugis yang artinya Tahun. Jadi Pattungeng berarti tradisi yang dilaksanakan setiap tahunnya secara turun temurun, sebagai bukti bahwa mereka senatiasa telah menjaga arwah leluhur yang telah meninggal. Tidak hanya itu, di tradisi inilah akan dilakukan upacara tradisional, sebagai realisasi pelepasan nazar setelah mendapatkan hasil panen selama satu tahun.

Tradisi dan budaya merupakan beberapa hal yang menjadi sumber dari akhlak dan budi pekerti. Tradisi merupakan suatu gambaran sikap dan perilaku manusia yang telah berproses dalam waktu lama dan dilakukan secara turun-temurun dimulai dari nenek moyang. Tradisi yang telah membudaya akan menjadi sumber dalam berakhlak dan berbudi pekerti seseorang. Manusia dalam berbuat akan melihat realitas yang ada di lingkungan sekitarnya sebagai upaya dari sebuah adaptasi walaupun sebenarnya orang tersebut telah mempunyai motivasi berperilaku yang sesuai dengan tradisi yang di lakukannya.

Tidak ada angka pasti mengenai sejak kapan masyrakat melaksanakan tradisi adat tersebut. Sejauh ini data yang ada bahwa keberadaan tradisi adat Pattaungeng tidak lepas dari peristiwa ditemukannya to manurung di Situs Tinco. Meskipun tidak disebutkan tentang kurung waktu kedatangan to manurung. (Tangke, 2001)

\section{a. Situs Tinco}

Dengan adanya peninggalan megalitik yang tersebar pada suatu tempat atau situs berarti masyarakat pernah menggunakan obyek tersebut sebagai medium untuk berhubungan dengan arwah leluhurnya. Di dalam melakukan aktifitas pemujaan inilah, maka setiap benda atau kebudayaan materil yang digunakan mempunya makna dan tujuan tertentu. Bentuk kebudayaan materil yang digunakan saling berhubungan antara bentuk yang satu dengan bentuk yang lainnya. Sedangkan lingkungan merupakan faktor utama lahirnya suatu kebudayaan atau tradisi. Seperti halnya di Tinco terdapat situs megalitik berupa batu yang dimana di yakini oleh masyarakat sekitar bahwa tempat menghilangnya Latemmamala (Datu Soppeng). Tradisi itu berlangsung tanpa mengenal jarak dan waktu, karena ia bisa terjadi dari hubungan antara manusia secara langsung maupun tidak langsung. Hal ini menyebabkan hasil kebudayaan megalitik Tinco sampai sekarang masih berkembang dalam masyarakat.

Di situs tinco terdapat beberapa titik penting yang mempunyai hubungan dengan peristiwa atau tokoh yang bersifat mitos seperti Lakelluaja ( peristiwa raib nya to manurung ketika sedang menggunting rambut nya), Petta Pallaongrumae (mitos tentang tokoh yang membawa pengetahuan yang berkaitan dengan pertanian) dan Petta Passaunge (mitos tentang tokoh yang memiliki kesenangan menyabung ayam). (Hasanuddin, 2016)

Situs Tinco adalah toponim yang mengacu kepada nama suatu daerah yang disebut dalam sumber lontarak sebagai pusat berdirinya kerajaan Soppeng yang pertama. Allangkanae, merupakan toponim ruang mengacu kepada nama suatu tempat tinggal raja (tempat berdirinya istana kerajaan). Tempat ini di tandai dengan pohon beringin yang diperkirakan umurnya sudah ratusan tahun. Matoa Tinco adalah tempat pemakaman raja soppeng yang pertama yaitu Matoa Tinco. Lakelluaja atau Petta Mallajangnge, yaitu tempat dimana datu Soppeng I La Temmamala Manurunge, mencukur rambutnya kemudian menghilang kembali ke angkasa sebagai tempat asalnya.

\section{Kepercayaan}

Nilai agama atau kepercayaan termasuk salah satu unsur nilai budaya leluhur yang terkandung dalam tradisi adat Pattaungeng di situs Tinco Kabupaten Soppeng. Perwujudan nilai agama atau kepercayaan dapat dilihat pada saat akan di mulai nya 
acara. Pada saat seperti ini pemangku adat yang memimpin tradisi terlebih dahulu membacakan doa keselamatan dan mantramantra, dimaksudkan agar acara tersebut dapat berjalan dengan lancar sampai selesai.

Kepercayaan keagamaam yang telah berkembang dimasyarakat setempat didasarkan pada kepercayaan manusia terhadap roh leluhur. Masyarakat percaya bahwa roh leluhur tersebut merupakan kekuatan tuhan yang ada di muka bumi ini. Kepercayaan roh leluhur tersebut dihubumhkan dengan kepercayaan animisme dan dinanisme yang telah lama berkembang di masyarakat jauh sebelum agama islam masuk. Kepercayaan animisme adalah kepercayaan terhadap arwah nenek moyang yang bersemayam disuatu tempat seperti batu dan pohon sedangkan kepercayaan dinamisme adalah kepercayaan terhadap benda yang di anggap gaib seperti jimat dan badik. Selain itu masyarakat juga sangat percaya adanya alam gaib yang merupakan asal dari kekuatan yang selama ini diagung-agungkan

Dimana di Tinco sebagian besar masyarakat nya menganut agama islam. Mereka berpandangan bahwa tradsi ini sangat perlu dilestarikan. Tradisi tersebut merupakan bentuk penghormatan kita terhadap To Manurung yang di temukan di Situs Tinco.

Meskipun masyarakat Tinco mayoritas beragama islam tetapi kepercayaan yang telah diwariskan oleh leluhur masih sangat kental dikehidupan mereka. Bahkan kepercayaan-kepercayaan tersebut telah menjadi pedoman hidup penganut nya. Sebagai ungkapan rasa syukur kepada tuhan atas limpahan rezeki maka dilaksanakan nya tradisi adat Pattaungeng Di situs Tinco.

\section{Pelaksanaan Tradisi Adat Pattaungeng Di Situs Tinco}

\section{a. Priode Tahun 2007-2011}

Tradisi adat pattaungeng mempunyai fungsi yang sangat besar bagi masyarakat karena tradisi pattaungeng merupakan peraturan tingkah laku atau tindakan yang harus dilakukan untuk menghargai para leluhur. Dengan demikian, pattaungeng merupakan kebudayaan mencakup tujuan kebudayaan maupun cara-cara yang dianggap baik untuk mencapai tujuan tersebut. Tradisi Pattaungeng memiliki peraturan-peraturan yang beranekaragam.

\section{1) Persiapan Pelaksanaan Tradisi}

Sebelum tradisi adat Pattaungeng dilaksanakan, terlebih dahulu melakukan tudang sipulung (musyawarah). Tudang sipulung adalah musyawarah yang dilakukan oleh masyarakat Tinco dengan pemangku adat dan keturunan matoa Tinco dan membicarakan kapan waktu tepat pelaksanaan tradisi adat Pattaungeng. Keputusan kapan pelaksanaan ditentukan oleh sanro, pemangku adat bersama masyarakat. Setelah adanya keputusan kapan pelaksanaan tradisi adat Pattaungeng maka masyarakat mulai mempersiapkan apa-apa saja yang di perlukan saat pelaksanaan tradisi adat Pattaungeng.

\section{2) Kelengkapan Pelaksanaan Tradisi}

Pada pelaksanaan tradisi adat Pattaungeng, maka satu minggu sebelum di mulai, panitia pelaksana sibuk mempersiapkan segala perlengkapan tradisi. Dalam mempersiapkan perlengkapan ini, mereka harus hati-hati dalam memilih bahan yang akan dipakai. Bahan yang digunakan tidak boleh bahan yang rusak atau busuk karena jika hal itu terjadi, proses tradisi tidak akan hikmat dan tidak akan diterima oleh para leluhur. Dana yang di gunakan untuk membeli perlengkapan yang digunakan saat tradisi di peroleh dari sumbamgan sukarela dari keturunan Matoa Tinco dan masyarakat setempat. Sumbangan tersebut dapat berupa uang ataun beras.

Adapun perlengkapan Tradisi yang dipersiapkan adalah:

1) Ayam kampung

2) Pisang ambon

3) Anreang sakke

4) Sokko fatanrufa

5) Minnya bau

6) Benno

7) Fesse

8) Kaluku tara bila 
9) Telur ayam

10) Kemenyan atau dupa

11) Kain putih

12) Leppe-leppe

Dapat diketahu bahwa dalam proses tradisi pattaungeng terdapat bahan-bahan dan alat-alat yang digunakan seperti yang telah disebutkan diatas. Dan memiliki makna-makna tersendiri dalam menyimbolkan tradisi pattaungeng.

\section{3) Proses Pelaksanaan Tradisi}

Pelaksanaan tradisi adat pattaungeng biasanya di adakan antara bulan okteber atau september. Dilaksanakan secara sederhana yaitu dengan membawa sesajen ke tempat pelaksanaan tradisi, adapun sesajen yaitu sokko fatanrufa, kaluku tarabila, anreang sakke yang terdiri dari salonde, bette bale, bette urang dan tempatempa. Keseluruhan sesajen tersebut di susun tepat di hadapan bongkahan batu yang dianggap tempat menghilang nya $L a$ Temmamala kemudian di bacakan doa-doa oleh Sanro. Tradisi tersebut hanya dihadiri oleh sanro, pemangku adat, keturunan Matoa Tinco dan masyarakat sekitar wilayah Tinco. Karena tradisi Pattaungeng merupakan hal yang sangat sakral bagi masyarakat setempat. Namun seiring berjalannya waktu, pegelaran tradisi ini mengalami perkembangan dalam hal pelaksanaan.

\section{b. Priode tahun 2012-2017}

Tradisi pattaungeng sendiri adalah tradisi yang diwariskan secara turun temurun oleh nenek moyang yang dilaksanakan untuk memanjatkan rasa syukur kepada tuhan karena mendapat hasil panen yang melimpah. Tradisi ini berlangsung dari masa ke masa, perlahan mengalami akulturasi di berbagai perkembangan di era setiap generasi.

\section{1) Persiapan Pelaksanaan Tradisi}

Sebelum tradisi adat Pattaungeng dilaksanakan, terlebih dahulu melakukan tudang sipulung (musyawarah). Tudang sipulung adalah musyawarah yang dilakukan oleh masyarakat yang dilaksanakan oleh masyarakat Tinco dengan pemangku adat dan ketua panitia pelaksanaan yang merupakan keturunan matoa Tinco dan membicarakan kapan waktu tepat pelaksanaan tradisi adat Pattaungeng yang biasanya dilaksanakan di rumah ketua panitia dan keputusan kapan pelaksanaan ditentukan oleh ketua panitia, sanro, pemangku adat bersama masyarakat. Setelah adanya keputusan kapan pelaksanaan tradisi adat Pattaungeng, ketua panitia beserta beberapa masyarakat Tinco kemudian menemui kepala Dinas Kebudayaan yakni untuk menyampaikan prihal yang telah mereka sepakati dari hasil Tudang Sipulung. Pemerintah dalam hal ini hanya mewadahi pelaksanaan tradisi adat Pattaungeng ini.

Bahan-bahan yang diperlukan dalam tradisi adat dipersiapkan, khususnya hewan kerbau yang merupakan hewan yang akan disembeli dalam proses tradisi adat Pattaungeng:Pelaksanaan tradisi adat pattaungeng ini biasa nya dilakukan setahun sekali yaitu setelah dilaksanankannya panen oleh masyarakat tinco.

\section{2) Kelengkapan Pelaksanaan Tradisi}

Pada pelaksanaan tradisi adat Pattaungeng di tahun 2012 berkat bantuan dari pemerintah kabupaten dalam hal ini diwakili oleh Dinas Kebudayaan dan Pariwisata, akhirnya pelaksanaan nya lebih meriah. Keikut sertaan pemerintah ini cukup meringankan beban masyarakat Tinco karena hampir semua kelengkapan Tradisi adat Pattaungeng di tanggung oleh pemerintah dalam hal nya yaitu Dinas Pariwisata dan Kebudayaan. Bahan-bahan yang digunakan hampir sama pada tahun sebelumnya seperti Ayam kampung, Pisang ambon, Anreang sakke, Sokko fatanrufa, Minnya bau, Benno, Fesse, Kaluku tara bila, Telur ayam, Kemenyan atau dupa, Kain putih, Leppe-leppe, Lawasoji yang hanya membedakan yaitu adanya hewan yang disembeli berupa seekor kerbau.

\section{3) Proses pelaksanaan tradisi}

Sebelum dimulainya tradisi adat Pattaungeng di Situs Tinco, terlebih dahulu disiapkan sesajen yang akan dibawa ke lokasi pelaksanaan, sesajen yang dimaksud 
berupa sokko fattangrufa, telur, pisang, kelapa dan leppe-leppe. Tidak lupa juga hewan yang akan disembeli yakni seekor kerbau yang telah dipersiapkan. Pembelian kerbau tersebut dari sumbangan dana SKPD yang telah diberikan pemerintah Kabupaten Soppeng. Selain itu juga alat musik genrang juga dipersiapkan untuk mengiringi Bissu pada saat tradisi adat tersebut berlangsung.

Mengenai kehadiran bissu masih diperlukan dalam melangsungkan prosesi tradisi adat. Hal ini disebabkan dalam adat masyarakat di sulawesi selatan terutama kalangan etnis bugis, Bissu dan upacara adat merupakan satu kesatuan yang tidak dapat dipisahkan. Meskipun bissu bertentangan dengan ajaran.

Rangkaian kegiatan dalam pelaksaan tradisi Pattaungeng di Situs Tinco Kelurahan Ompo Kecamatan Lalabata Kabupaten Soppeng Berlangsung selama dua hari dan biasanya dilaksanakan pada bulan september atau oktober. Adapun rangkaian kegiatan yang dilakukan selama dua hari diantaranya:

1. Mappalemme/Mappatudang rekko ota ( mengubur daun siri)

2. Menjemput Arajang ( benda pusaka)

3. Pemotongan Kerbau

4. Sambutan

Kearifan lokal adalah pengetahuan yang dikembangkan oleh para leluhur dalam mensiasati lingkungan hidup sekitar mereka, menjadikan pengetahuan itu sebagai bagian dari budaya dan memperkenalkan serta meneruskan itu dari generasi ke generasi. Beberapa bentuk pengetahuan tradisional itu muncul lewat cerita-cerita, legenda-legenda, nyanyiannyanyian, ritual-ritual, dan juga aturan atu hukum setempat. (Nuraeni \& Alfan, 2012)

\section{4) Eksistensi Tradisi Adat Pattaungeng Di}

\section{Situs Tinco}

Kehidupan manusia berjalan mengikuti alur waktu, setiap proses perjalanannya banyak hal yang terjadi dalam kehidupan manusia. Tindakan dan tingkah laku manusia terjadi bukan tanpa sebab melainkan sebuah proses interaksi manusia itu sendiri, tindakan tersebut memiliki fungsi tersendiri mungkin saja akan membentuk rasa solidaritas masyarakat. Salah satu contoh yang dapat kita lihat yaitu sebuat tradisi dan adat-istiadat itu dipertahankan sampai saat ini dan memiliki fungsi.

Tradisi menjadi bagian dari hasil kreasi manusia dalam mengembangkan potensi yang dimilikinya sebagai mahkluk ciptaan Allah Swt. di muka bumi Dalam menjalankan fungsinya sebagai khalifah manusia mengatur kehidupannya berdasarkan aturan dari agamanya demi terwujudnya hidup yang diridhai-Nya, menjalin hubungan dengan sesama makhluk berdasarkan petunjuk dan tuntunan agama sehingga segala bentuk aktivitasnya baik berupa adat-istiadat, norma, kebiasaan atau tradisi harus sejalan dengan syari'at.

Sulawesi Selatan sejak dahulu sampai saat sekarang terbangun dari pola tertentu yang dalam diskusi ini disebut pola budaya atau Budaya Sulawesi Selatan. berbagai studi menunjukkan bahwa budaya Sulawesi Selatan dapat ditemukan dan terangkum dalam konsep Panngaderreng (Bugis) atau Panngadakkang (Makassar). kedua konsep tersebut berasal dari kata dasar Adeq (Bugis) dan Adaq (Makassar), yang berarti Adat.

\section{Upaya Pemerintah dan Masyarakat dalam mempertahankan Tradisi Adat Pattaungeng}

Akulturasi kebudayaan hanya dapat bergerak dalam ruang kebudayaan yang adiptif dengan tingkat resestensif yang tidak terlalu tinggi. Berbagai elemen sosial yang ada didakam masyarakat tinco menjadi alat dukungan terjadinnya proses akulturasi. Elemen politik, ekonomi dan nalar budaya merupakan faktor pergerak terjadinya akulturasi kebudayaan. Adaptasi kebudayaan pendatang hanya dapat terjadi apabila elemen-elemen internal dapat mendukung. (Ismail, 2012)

\section{a. Pemerintah}

Dinas Kebudayaan dan Pariwisata Kabupaten Soppeng merupakan Satuan 
Kerja Perangkat Daerah yang secara khusus menaungi kebudayaan asli Kabupaten Soppeng. Berkaitan dengan hal tersebut, di tahun 2012 pemerintah mulai memfasilitasi anggaran yang dibutuhkan oleh masyarakat Tinco dalam melaksanakan Tradisi Adat Pattaungeng. Perintah menganggarkan sekitar 10 juta dari dana SKPD. Pemerintah juga melakukan renovasi di tempat dilaksanakan nya tradisi seperti perbaikan bangunan di situs tinco, pembangunan baruga, wc, serta dapur.

Upaya pemerintah dalam mempertahan tradisi adat pattaungeng di situs tinco yaitu dengan mengajak masyarakat setempat untuk tetap melaksanakan tradisi tersebut tiap tahunnya. Dan mesosialisasikan kepada masyarakat agar tetap menjaga warisan kebudayaan leluhur nenek moyang.

\section{b. Masyarakat}

Masyarakat Tinco sangat berperan penting dalam mempertahankan Tradisi Adat Pattaungeng. Karena mereka menanamkan dalam diri mereka untuk membudayakan dan melestarikan warisan nenek moyang. Adanya kecintaan dan terhadap budaya itu sendiri, adanya penerus atau pergantian generasi yang akan melaksanakan sehingga budaya tersebut tetap terlaksana dan bertahan didalam masyarakat.

Kegiatan ini dilakukan untuk mengingat para leluhur dan mengingat akan rasa nikmat, syukur, dan kebahagiaan yang dirasakan keturunannya. Seacar spritual menurut kepercayaan masyarakat setempat, apabila kita melakukan tradisi seperti itu para arwah leluhur kita juga ikut datang duduk bersama menikmati makanan yang disajikan dan merasakan kenikmatan dalam kuburnya karna mendapat kiriman doa dari para keturunannya yang masih hidup. Bagaimana pun rangkain tradisi adat Pattaungeng ini telah dilakukan oleh orang terdahulu yang tidak bisa kita lupakan. Maka dari itulah sebagai keturunannya, masyarakat Tinco melaksanakan kegiatan tersebut setiap tahunnya.

\section{Tradisi Adat Pattaungeng Di Situs Tinco Sebagai Objek Wisata}

Kawasan Watansoppeng memiliki sumber daya budaya (SDB) yang beragam. Sumberdaya budaya yang dimaksud adalah tinggalan budaya Kerajaan Soppeng baik yang berupa material (sumberdaya Arkeologi) maupun yang non-material (tradisi-tradisi tradisional yang masih berlangsung). Sebaran SDB seperti kompleks Istana Datu Soppeng dan peninggalan kolonial di Kota Watansoppeng menimbulkan kesan sebagai kota tua bersejarah.

Masyarakat Sulawesi Selatan juga mengenal Watansoppeng sebagai kota dengan sumberdaya alam yang khas. Keindahan lansekap kota yang bergelombang dan ribuan kelelawar yang bergantungan di pohon asam di jantung Kota Watansoppeng, yang merupakan daya tarik kawasan ini. Masyarakat Sulawesi Selatan bahkan memberi julukan Watansoppeng sebagai kota kelelawar.

Pengembangan suatu daerah tujuan wisata dimulai dengan mengidentifikasi jenis objek yang hendak dikembangkan, hal tersebut berkenaan dengan warisan alam yang dimiliki oleh suatu daerah atau objek wisata peninggalan nenek moyang sebagai peninggalan sejarah dalam hal ini berupa cara ritual penyembahan. Penting diperhatikan dalam pengembangan suatu daerah tujuan wisata agar dapat menarik untuk dikunjungi oleh wisatawan harus memiliki 2 syarat yakni, something to see (sesuatu yang dapat dilihat), dan something to do (sesuatu yang dapat dilakukan)

Seperti halnya tradisi adat pattaungeng disitus tinco, merupakan salah satu kebudayaan masyarakat Kabupaten Soppeng yang dilakukan secara turun temurun kerena merupakan warisan dari nenek moyang. Maka dari itu tradisi adat pattaungeng memiliki daya tari wisata. Berdasarkan syarat yang disebutkan sebelumnya, tradisi ada Pattaungeng memiliki suatu rangkaian acara yang cukup menarik dilihat mulai dari menjemput arajangnge sampai dengan acara mappadendang. Hal tersebut termasuk 
dalam syarat something to see (sesuatu yang dapat disaksikan).

Selain itu wisatawan yang menyaksikan tradisi adat Pattaungeng di Situs tinco juga bisa ikut serta dalam kegiatan tersebut, namun tidak dengan acara inti. Karenan acara inti hanya dapat diikuti oleh keturunan Matoa Tinco. Seperti hal nya ikut menikmati hidangan yang disediakan setelah acara tradisi adat Pattaungeng selesai. Hal tersebut termasuk syarat something to do (sesatu yang dilakukan).

Selain syarat tersebut, tradisi adat Pattaungeng di Situs Tnco yang memiliki nilai sejarah sehingga dikategorikan sebagai objek wisata. Dengan dilaksanakan nya tradisi tersebut diharapkan wisatawan dapat mengetahui asal usul tradisi adat Pattaungeng di Situs Tinco dan kaitannya dengan menghilangnya La Temmamala yang merupakan Raja Soppeng yang pertama, di kawasan Situs Tinco. Hal tersebut dapat memberikan pengetahuan sejarah secara tidak langsung.

Situs tinco yang merupakan tempat terlaksanakannya tradisi adat Pattaungeng, beberapa tahun terakhir ini mulai dikelola dan dijadikan objek wisata bersejarah oleh Dinas Kebudayaan dan Pariwisata Kabupaten Soppeng.

\section{E. Kesimpulan}

Dilaksanakannya tradisi Pattaungeng di Situs Tinco Kelurahan Ompo Kecamatan Lalabata Kaupaten Soppeng, sebagai bukti bahwa mereka senatiasa telah menjaga arwah leluhur yang telah meninggal. Tidak hanya itu, di tradisi inilah akan dilakukan upacara tradisional, sebagai realisasi pelepasan nazar setelah mendapatkan hasil panen selama satu tahun. Hal ini dimaksudkan sebagai tanda syukur kepada nenek moyang.

Dari segi perkembangan tradisi Pattaungeng mengalami perubahan yang begitu pesat baik dari segi peralatan, pelaksanaan, pengunjung maupun lokasi situs itu sendiri. Pada awal kemunculan tradisi Pattaungeng, pemujaan hanya dilakukan beberapa keluarga yang dianggap sebagai keturunan. Namun, ditahap perkembangan selanjutnya masyrakat lain pun ikut berpartisipasi dalam pegelaran ini. Bahkan sejak tahun 2012 pelaksanaan tradisi Pattaungeng sudah di ambilalih oleh pemerintah daerah dalam hal ini Dinas Kebudayaan dan Pariwisata Kabupaten Soppeng.

Tradisi Pattaungeng adalah tradisi yang dilaksanakan oleh seluruh masyarakat Tinco. Dalam tradisi ini terjalin interaksi sosial yang baik, membangun solidaritas yang kuat antar masyarakat lainnya. Begitu pula dalam segi keagamaan, walaupun agama islam telah resmi masuk dan berkembang dimasyarakat, namun kepercayaan nenek moyang mereka masih tetap dipegang teguh.

\section{F. Daftar Pustaka}

Arafiky, R., 2017. Tradisi Pattaungeng di Situs Bulu Matanre Desa Mattabulu Kecamatan Lalabata Kabupaten Soppeng (1990-2015). Makassar: Fakultas Ilmu Sosial Universitas Negeri Makassar.

Hamid, A. R. \& Madjid, M. S., 2008. Pengantar Ilmu Sejarah. Makassar: Rayhan Intermedia.

Hasanuddin, 2016. Lembah Walennae. Yogyakarta: Ombak.

Madjid, M. D., 2014. Ilmu Sejarah Sebuah Pengantar. Jakarta: Kencana.

Nuraeni, H. G. \& Alfan, M., 2012. Studi Budaya Indonesia. Bandung: CV Pustaka Setia.

Purwadi, 2007. Adat-Istiadat Budaya Jawa. Yogyakarta: Sahidia.

Sjamsuddin, H., 2007. Metodologi Sejarah. Yogyakarta: Ombak.

Tangke, A. W., 2001. Soppeng Merangkai Esok. Makassar: Pustaka Refleksi.

Wahid, S., 2007. Manusia Makassar. Makassar: Pustaka Refleksi. 